\title{
Exploring Entrepreneurial Orientation (EO) of Public and Third Sector Organisations at Employee/ Volunteer Level
}

\author{
Anna Rogowska \\ Department of Management and Organisation, Centre for Enterprise Development and \\ Regional Economy (CEDRE), Waterford Institute of Technology \\ Waterford, Ireland. \\ Dr. Valerie Brett \\ Department of Management and Organisation, Centre for Enterprise Development and \\ Regional Economy (CEDRE), Waterford Institute of Technology \\ Waterford, Ireland. \\ Prof. Bill O'Gorman \\ Department of Management and Organisation, Centre for Enterprise Development and \\ Regional Economy (CEDRE), Waterford Institute of Technology \\ Waterford, Ireland.
}

(C) Anna Rogowska, Valerie Brett and Bill O'Gorman. This work is licensed under the Creative Commons Attribution-NonCommercial-ShareAlike 4.0 International License. To view a copy of this license, visit https://creativecommons.org/licenses/by-nc-sa/4.0/ .

\section{Abstract}

Public and third sector employees are facing increasing pressure to behave more entrepreneurially in their day-to-day work (Wakkee, Elfring and Monaghan, 2010). Literature on entrepreneurial orientation (EO) highlighted that EO enhances organisational performance, firms' competiveness and product innovation (Rauch et al., 2009; Lumpkin and Dess, 2001). While previous studies on EO have applied the concept in relation to the overall performance of an organisation (Wiklund and Shepherd, 2005), this research explores EO at the individual level (Jelenc, Pisapia and Ivanušić, 2015; Bolton and Lane, 2012; Okhomina, 2010).

The aim of the research is to identify entrepreneurial potential of employees in public and third sector organisations through an Entrepreneurial Orientation perspective. This provides a means to explore potential entrepreneurial behaviour by determining past experience of employees and the extent to which they behave proactively in their current job roles, as opposed to identifying entrepreneurial traits of volunteers and employees.

This research is based on a large European study which explored the EO of 450 employees/volunteers, representing 216 public and third sector organisations spanning across six European countries, including Ireland (South East Region), Iceland, Bulgaria, Greece, Italy (Sicily) and Portugal. This study is a preliminary investigation and the research indicates the value in pursuing this area further. The preliminary findings illustrate that 
potentially employees in public and third sector organisations in Iceland and Ireland are more "entrepreneurial" in comparison to the other countries surveyed. Furthermore, the research indicates that there is a relationship between employees/volunteers that display entrepreneurial experience, their educational attainment, and the degree to which they feel empowered in the decision-making processes or are encouraged to seek new opportunities within their work environments.

Keywords: Entrepreneurial orientation; EO; Public sector organisations; Third sector organisations

\subsection{Introduction}

There is a recognition that public and third sector organisations and their employees/volunteers need to be more entrepreneurial and innovative in pursuit of economic and social development (Diefenbach, 2011; Morris, Webb and Franklin, 2011). This relates to the manner in which public, not-for-profit organisations (NPOs) and communities manage their domains, organise their work and deliver services to their customers. According to Gibb (2002), there is more emphasis and responsibility placed on the role of employees within these organisations in performing their dayto-day duties, hence forcing them to behave more entrepreneurially at work (Wakkee, Elfring and Monaghan, 2010; Zampetakis and Moustakis, 2010; Mair, 2005).

Research into the drive to stimulate and support entrepreneurial behaviour in public sector services has significantly grown over the last two decades (Bysted and Hansen, 2015; Kim, 2010; Zerbinati and Souitaris, 2005) as there is a perceived need to balance the socially driven mission with entrepreneurial actions to deliver greater financial sustainability and efficiency in public sector and not-for-profit organisations (NPO). Also there is evidence to suggest that the community and voluntary sector increasingly makes a valuable contribution to sustaining what is often referred to as 'civil society" ; the part of society that is neither in the domain of the state nor the private sector (Defourny and Nyssens, 2010). As a result there is increased interest in studying entrepreneurial behaviour within all types of organisations, regardless of size, age, or industry sector (Kraus, 2013; Zampetakis and Moustakis, 2010; Chell, 2007; Mair, 2005). Entrepreneurial behaviour within organisations (also called intrapreneurship) is regarded as a vehicle for organisational change, a way to improve performance which is essential for innovation (Kearney, Hisrich and Roche, 2008). Moreover, Mair (2005) evoked that entrepreneurial behaviour supports employees on a day-to-day basis in becoming more effective, more alert to innovation and more opportunity-focused.

With respect to entrepreneurial behaviour, entrepreneurial orientation (EO) is a significant resource for achieving greater performance and competitive advantage (Wiklund and Shepherd, 2005; Covin and Slevin, 1991), particularly through individuals' innovative, risky and proactive behaviour (Morris and Kuratko, 2002). EO represents a unique resource for organisations because it cannot be purchased and it is difficult to imitate, as firms invest considerable time in nurturing their EO cultures (Lee and Peterson, 2000). EO can apply to both the organisations and the individual

\footnotetext{
${ }^{1}$ Civil society is called the "third sector" of society, along with government and business. It comprises civil society (community and voluntary sector organisations) and non-governmental organisations http://www.un.org/en/sections/resources/civil-society/index.html
} 
(Covin and Lumpkin, 2011), as it is primarily concerned with entrepreneurial behaviour, rather than entrepreneurial traits (Covin and Slevin, 1991).

Although an abundance of literature exists pertaining to the moderating factors of EO at the organisational level (Miller, 2011), the past experience of an individual's entrepreneurial orientation has received limited attention (Jelenc, Pisapia and Ivanušić, 2015; Altinay and Wang, 2011; Okhomina, 2010).

\subsection{Theoretical frame}

Entrepreneurship is a multidimensional concept that can take place in multiple sites and spaces (Steyaert and Katz, 2004) and is a matter of everyday activities rather than the reserve of an elitist group of entrepreneurs (Gibb, 2002); hence, it should not be seen solely from a business perspective (Cooney and Murray, 2008). Thus, entrepreneurial behaviour and innovation holds the potential to flourish in public and third (including voluntary and social enterprise) sector organisations, but organisational support and encouragement is also important (Bysted and Hansen, 2015; Kuratko, Hornsby and Covin, 2014).

Public sector organisations are facing a dynamic, hostile, and complex set of environmental conditions, with increasing expectations to offer more public choices and to enhance public value creation (Moore, 1995). Literature regarding the public sector has repeatedly suggested that these organisations should become more entrepreneurially oriented as a way to respond to these challenges (Stewart, 2014; Kim, 2010; Currie et al., 2008; Borins, 2002). Kim (2010) supported the concept that the public sector needs to be aligned to stimulate entrepreneurial activities and that employees should be allowed to function beyond the remit of their job description, as organisational rigidity can hinder entrepreneurial and risk-taking behaviour.

While in the private sector antecedents and consequences of a firm's entrepreneurial orientation (EO) have been studied extensively, such research in the public sector is scant (Westrup, 2013; Diefenbach, 2011). In particular, there is limited knowledge about the actual antecedents of EO that stimulate public administration or voluntary staff to be innovative, proactive, and even to some extent risk-taking, in their organisations (Diefenbach, 2011; Currie et al., 2008).

According to Stewart (2014) implementing innovation in the public sector is not so simple, as "many innovative initiatives run against many restrictions and limitations, precisely because they challenge many existing systems, values and processes in the host agencies" (p. 241). Moreover, within social enterprise organisations, an increased demand for services provides reduced funding and increases costs associated with managing their domains (Venables, 2015; Grover and Piggott, 2012). Thus, the challenge that established organisations face is harnessing the energy of highly motivated and opportunity-driven employees who are willing to pursue new products, processes or services in their organisations (Wakkee, Elfring and Monaghan, 2010).

Entrepreneurial orientation (EO) has its origins in strategic management literature and has emerged as a firm-level phenomenon based on the seminal works of Miller (1983) and Covin and Slevin (1989) (all cited in Rauch et al., 2009). EO entails the process aspect of entrepreneurship (Lumpkin and Dess, 1996) and generally refers 
to a firm's propensity to be innovative, to be proactive and to take risks (Andersén, 2010). EO is primarily concerned with entrepreneurial behaviour, rather than with entrepreneurial traits (Covin and Slevin, 1991). This refers to the culture within the organisation in terms of how it supports, encourages and empowers employees to seek out and implement new opportunities based on their own initiative. Furthermore, encouraging the development of innovative behaviour has a far greater chance of success if the environment is entrepreneurial in nature (Feldman and Francis, 2004). While EO has been predominantly applied at the firm level, Covin and Lumpkin (2011) argued that the EO analysis varies considerably from SMEs, large organisations to multi-business organisations and, further, the authors contest the view that "...individuals can, for example, exhibit a proclivity toward entrepreneurial thought and action" (p. 857). Such multidimensional views on EO have opened up new research avenues within the EO space, such as the current study which explores the entrepreneurial potential of employees/volunteers in public and third sector organisations through an EO perspective.

\subsection{Method}

Organisations in the public, voluntary, and social enterprise (SE) sectors were surveyed in six European countries (Bulgaria, Greece, Iceland, Ireland, Portugal and Italy (Sicily)). Individuals from the third and public sectors, regardless of their job roles, were randomly selected and invited to participate in the survey. In total, 450 respondents from 216 organisations were surveyed across the six countries, with the public sector registering the highest number of respondents at $49 \%$, followed by the social enterprise sector at $35 \%$ and finally a small sample of voluntary organisations at $16 \%$ (see Figure 1).

Figure 1: Respondents by sector (source: authors)

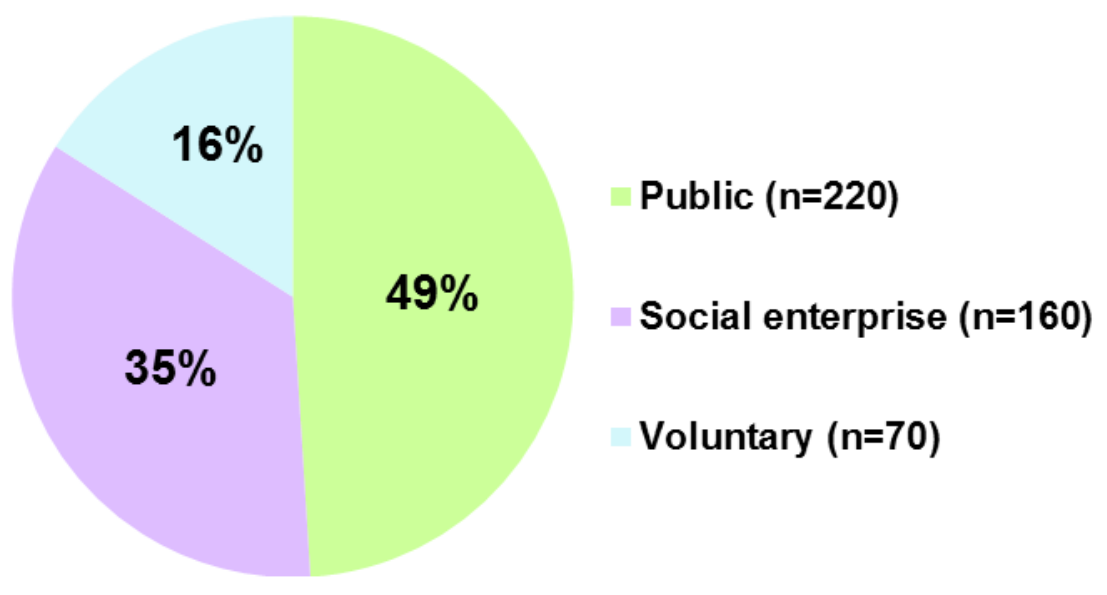

Post an initial pilot survey of six randomly selected respondents from each country, the data was collected over a two month period, electronically by distributing a 
survey questionnaire (translated into each country's original language) by email and by post (in Bulgaria, Greece and Portugal) and via Survey Monkey portal (in Ireland, Iceland, and Sicily). Although the data collection processes varied slightly from country to country, the data was analysed by country, by organisation type and gender manually by using Excel Spreadsheets.

Prior to administering the survey, the minimum sample size was established at 50 respondents per country. However, a relatively small number of respondents were surveyed in the voluntary sector, in comparison to the respondents in the public sector where the number of respondents who replied to the survey was three times higher. Table 1 details the number of respondents surveyed and the number of organisations involved by country surveyed.

Table 1: Response rate, number of respondents and organisations surveyed

\begin{tabular}{cccccc}
\hline Country & $\begin{array}{c}\text { Targeted } \\
\text { sample size }\end{array}$ & $\begin{array}{c}\text { Total } \\
\text { Surveyed }\end{array}$ & $\begin{array}{c}\text { Number of } \\
\text { valid } \\
\text { Responses }\end{array}$ & $\begin{array}{c}\text { Response } \\
\text { Rate }\end{array}$ & $\begin{array}{c}\text { Number of } \\
\text { organisations }\end{array}$ \\
\hline Bulgaria & 50 & 170 & 50 & $29.40 \%$ & 34 \\
Greece & 50 & 249 & 49 & $21.20 \%$ & 19 \\
Iceland & 50 & 501 & 40 & $8.20 \%$ & 34 \\
Ireland & 50 & 225 & 50 & $23.10 \%$ & 31 \\
Portugal & 50 & 568 & 209 & $37.00 \%$ & 71 \\
Sicily & 50 & 216 & 52 & $24.70 \%$ & 27 \\
$\begin{array}{c}\text { Total } \\
\text { no. }\end{array}$ & $\mathbf{3 0 0}$ & $\mathbf{1 9 2 8}$ & $\mathbf{4 5 0}$ & - & $\mathbf{2 1 6}$ \\
\hline
\end{tabular}

Table 1 informs that the targeted sample size was 50 respondents per country. However, in the case of Portugal the sample size was very high $(n=568)$ and the response rate was the highest of the six countries surveyed at $37 \%$. This yielded a total of 209 valid responses, which was an unexpected outcome of the research. In Portugal, the survey was distributed by email and by post and was sent to as many as 71 organisations, with the feedback from the region that the survey was well received.

\subsection{Findings}

The findings are divided into three sections. The first section, 3.1, presents the demographics of the survey sample in terms of gender spilt, sector split (public, voluntary and social enterprise), employment level (senior executives, middle management or operative level) and the highest educational attainment of each respondent (from second level to $\mathrm{PhD}$ and other types of qualifications). Section 3.2 presents the entrepreneurial orientation of employees/volunteers; and the final section, 3.3, presents the entrepreneurial orientation of the surveyed organisations. 


\subsection{Demographics}

The public sector represented $50 \%$ of the Icelandic respondents and $60 \%$ of Irish and Greek respondents, while the social enterprise sector included more than half of the survey's respondents in both Bulgaria (64\%) and Sicily (56\%). As can be seen in Ireland and Sicily, the number of respondents is almost equally represented by females and males. Overall, across all the surveyed countries there were more female respondents (248), than male respondents (203) (See Table 2):

Table 2: Number of respondents surveyed per sector, gender and country

\begin{tabular}{|c|c|c|c|c|c|c|c|c|c|c|c|c|c|c|c|}
\hline \multirow{2}{*}{$\begin{array}{c}\text { Country } \\
\text { Sector/Gender }\end{array}$} & \multicolumn{2}{|c|}{ Bulgaria } & \multicolumn{2}{|c|}{ Greece } & \multicolumn{2}{|c|}{ Iceland } & \multicolumn{2}{|c|}{ Ireland } & \multicolumn{2}{|c|}{ Portugal } & \multicolumn{2}{|c|}{ Sicily } & \multicolumn{2}{|c|}{$\begin{array}{c}\text { Total No. } \\
\text { of } M / F \\
\text { per } \\
\text { sector }\end{array}$} & \multirow{2}{*}{$\begin{array}{c}\begin{array}{c}\text { Total No. of } \\
\text { Respondents } \\
\text { per sector }\end{array} \\
\text { F/M }\end{array}$} \\
\hline & $M$ & $\mathrm{~F}$ & M & $\mathrm{F}$ & M & $\mathrm{F}$ & $M$ & $\mathrm{~F}$ & M & $\mathrm{F}$ & $M$ & $\mathrm{~F}$ & M & $\mathrm{F}$ & \\
\hline Public & 3 & 6 & 12 & 17 & 9 & 11 & 16 & 14 & 43 & 85 & 3 & 1 & 86 & 134 & 220 \\
\hline Voluntary & 4 & 5 & 0 & 0 & 4 & 9 & 4 & 5 & 16 & 4 & 12 & 7 & 40 & 30 & 70 \\
\hline Social E & 11 & 21 & 10 & 10 & 2 & 5 & 5 & 6 & 37 & 24 & 12 & 17 & 77 & 83 & 160 \\
\hline Total no. of $M / F$ & 18 & 32 & 22 & 27 & 15 & 25 & 25 & 25 & 96 & 113 & 27 & 25 & 203 & 247 & 450 \\
\hline $\begin{array}{l}\text { Total no. of } \\
\text { respondents }\end{array}$ & \multicolumn{2}{|c|}{50} & \multicolumn{2}{|c|}{49} & \multicolumn{2}{|c|}{40} & \multicolumn{2}{|c|}{50} & \multicolumn{2}{|c|}{209} & \multicolumn{2}{|c|}{52} & \multicolumn{2}{|c|}{450} & 450 \\
\hline
\end{tabular}

[F-females, M-males, Social E- social entreprise]

As illustrated in Table 2, there is a high number of respondents from the Portuguese sample, especially those from the public sector ( 85 females, 43 males). The high number of survey responses in Portugal was an unexpected outcome and may relate to the fact the survey was sent online to many public sector organisations that included a high number of employees. ${ }^{2}$

Table 3 illustrates the total number of male and female respondents across sector organisations from each of the six countries ${ }^{3}$, who indicated their level of employment and the type of job roles they perform within their organisations.

\footnotetext{
${ }^{2}$ Most of the municipalities surveyed in Portugal employ a relatively high number of staff, approx. 50-125 employees; this is a higher number in comparison to the other surveyed countries.

${ }^{3}$ As regards Greece, there were no responses to these questions.
} 
Table 3 : Employment role by gender, sector and country

\begin{tabular}{|c|c|c|c|c|c|c|c|c|c|c|c|c|c|}
\hline \multirow[b]{2}{*}{ Country } & \multirow{2}{*}{$\begin{array}{l}\text { Country } \\
\text { Employment Level }\end{array}$} & \multicolumn{2}{|c|}{ Bulgaria } & \multicolumn{2}{|c|}{ Greece } & \multicolumn{2}{|c|}{ Iceland } & \multicolumn{2}{|c|}{ Ireland } & \multicolumn{2}{|c|}{ Portugal } & \multicolumn{2}{|c|}{ Sicily } \\
\hline & & M & $F$ & $M$ & $\mathrm{~F}$ & M & $F$ & $M$ & $\mathrm{~F}$ & M & $\mathrm{F}$ & $\mathrm{M}$ & $\mathrm{F}$ \\
\hline \multirow{3}{*}{ Public } & Senior Ex. & 2 & 1 & - & - & 4 & 4 & 5 & 1 & 13 & 0 & 2 & 1 \\
\hline & Middle Manager & 0 & 0 & - & - & 5 & 7 & 4 & 3 & 0 & 0 & 1 & 0 \\
\hline & Operatives & 1 & 5 & - & - & 0 & 0 & 7 & 10 & 30 & 85 & 0 & 0 \\
\hline \multirow{3}{*}{ Voluntary } & Senior Ex. & 1 & 3 & - & - & 2 & 6 & 0 & 1 & 8 & 0 & 1 & 4 \\
\hline & Middle Manager & 2 & 2 & - & - & 2 & 3 & 2 & 2 & 0 & 0 & 9 & 2 \\
\hline & Operatives & 1 & 0 & - & - & 0 & 0 & 2 & 2 & 8 & 4 & 2 & 1 \\
\hline \multirow{3}{*}{ Social E } & Senior Ex. & 8 & 7 & - & - & 0 & 3 & 3 & 3 & 23 & 0 & 3 & 6 \\
\hline & Middle Manager & 0 & 1 & - & - & 2 & 2 & 1 & 0 & 0 & 0 & 6 & 9 \\
\hline & Operatives & 3 & 13 & - & - & 0 & 0 & 1 & 3 & 14 & 24 & 3 & 2 \\
\hline \multicolumn{2}{|c|}{ Total no. of M/F per country } & 18 & 32 & - & - & 15 & 25 & 25 & 25 & 96 & 113 & 27 & 25 \\
\hline \multicolumn{2}{|c|}{ Total no. of respondents } & \multicolumn{2}{|l|}{50} & \multicolumn{2}{|c|}{ No Data } & \multicolumn{2}{|l|}{40} & \multicolumn{2}{|l|}{50} & \multicolumn{2}{|c|}{209} & \multicolumn{2}{|l|}{52} \\
\hline
\end{tabular}

[M-males; F-females; Senior Ex. - senior executives]

In Iceland, all respondents are either senior executives or hold middle management positions in their organisations; these roles are also equally distributed among female and male respondents in the public sector. In the public sector in Portugal and Ireland, there were more males who are in 'senior management' roles, in comparison to females who hold rather more administrative or 'operative' roles. For example, in Portugal, across all the sectors, there is a notable contrast in roles held by females and males, with more males holding senior management positions (44 out of 96), and with all 113 females holding 'operative' roles.

Respondents were requested to indicate their highest level of educational attainment which is illustrated in Table 4. The majority of respondents in the Bulgarian public sector reported a relatively low level of educational attainment that is, a certificate level of education (38 out of 50). A similar finding is reported in Portugal, where more than half of the female respondents (53 out of 85 ) attained as their highest level of education either at second level (21) or a certificate degree (32). Moreover, the level of education attained among males and females in the public sector in Portugal is similar. However, five of the female respondents have a $\mathrm{PhD}$ (in the public sector) in comparison to none of the male respondents. Overall, it was surprising to see that in Portugal, of the total number of 209 respondents, there were only 5 respondents who attained a PhD. 
Table 4: The level of education attainment

\begin{tabular}{|c|c|c|c|c|c|c|c|c|c|c|c|c|c|}
\hline \multirow{2}{*}{ Sector } & \multirow{2}{*}{$\begin{array}{l}\text { Education } \\
\text { level }\end{array}$} & \multicolumn{2}{|c|}{ Bulgaria } & \multicolumn{2}{|c|}{ Greece } & \multicolumn{2}{|c|}{ Iceland } & \multicolumn{2}{|c|}{ Ireland } & \multicolumn{2}{|c|}{ Portugal } & \multicolumn{2}{|c|}{ Sicily } \\
\hline & & $M$ & $F$ & $M$ & $F$ & $M$ & $F$ & $M$ & $F$ & $\mathbf{M}$ & $F$ & $M$ & $F$ \\
\hline \multirow{7}{*}{ Public } & Second & & & & & & & 1 & & 13 & 21 & & \\
\hline & Certificate & 3 & 4 & & & 1 & 1 & & 1 & 10 & 32 & & \\
\hline & Degree & & & & 10 & & 7 & & 5 & 15 & 18 & 3 & 1 \\
\hline & P Grad & & & 8 & 5 & 8 & 2 & 12 & 6 & 5 & 9 & & \\
\hline & Ph.D. & & 2 & 4 & 2 & & & 3 & 2 & & 5 & & \\
\hline & Other & & & & & & 1 & & & & & & \\
\hline & Total M/F & 3 & 6 & 12 & 17 & 9 & 11 & 16 & 14 & 43 & 85 & 3 & 1 \\
\hline \multirow{7}{*}{ Voluntary } & Second & 1 & 2 & - & - & & & & 1 & & & & \\
\hline & Certificate & 2 & 2 & - & - & 1 & 1 & & 1 & 6 & & 2 & 1 \\
\hline & Degree & & & - & - & & 4 & 1 & 2 & 10 & 4 & 5 & 2 \\
\hline & $P$ Grad & & & - & - & 2 & 3 & 2 & 1 & & & 5 & 3 \\
\hline & Ph.D. & 1 & 1 & - & - & 1 & 1 & 1 & & & & & 1 \\
\hline & Other & & & - & - & & & & & & & & \\
\hline & Total M/F & 4 & 5 & - & - & 4 & 9 & 4 & 5 & 16 & 4 & 12 & 7 \\
\hline \multirow{7}{*}{ Social E } & Second & 1 & 1 & & 1 & & & & & 4 & 5 & & \\
\hline & Certificate & 9 & 18 & & 2 & 1 & 1 & & & & & 1 & 2 \\
\hline & Degree & 1 & & 6 & & & 1 & & 1 & 33 & 19 & 7 & 8 \\
\hline & P Grad & & & 4 & 6 & 1 & 2 & 4 & 4 & & & 4 & 6 \\
\hline & Ph.D. & & 2 & & 1 & & & & 1 & & & & 1 \\
\hline & Other & 0 & 0 & & & & 1 & 1 & & & & & \\
\hline & Total M/F & 11 & 21 & 10 & 10 & 2 & 5 & 5 & 6 & 37 & 24 & 12 & 17 \\
\hline \multicolumn{2}{|c|}{ Total no. of M/F per country } & 18 & 32 & 22 & 27 & 15 & 35 & 25 & 25 & 96 & 113 & 27 & 25 \\
\hline \multicolumn{2}{|c|}{ Total no. of respondents } & \multicolumn{2}{|c|}{50} & \multicolumn{2}{|c|}{49} & \multicolumn{2}{|c|}{40} & \multicolumn{2}{|c|}{50} & \multicolumn{2}{|c|}{209} & \multicolumn{2}{|c|}{52} \\
\hline
\end{tabular}

[Sec-second level of education; M-males; F-females; P Grad- Post Graduate] (

In contrast, in Ireland, Iceland and Greece the level of educational attainment is relatively high, with most of the respondents holding a post graduate degree, at 29 out of 50, 18 out of 40 and 23 out of 49, respectively. For example, in Ireland the education attainment among respondents is relatively high with $58 \%$ of respondents holding a post graduate level of education, of which $62 \%$ are from the public sector.

\subsection{Entrepreneurial orientation of employees/volunteers}

To identify existing entrepreneurial orientation of individuals/volunteers working within the public and third sectors, survey respondents were asked if they had any past entrepreneurial experience (see Table 5), and what was the category of their experience (for example owner of a business, or had established a club or society). Table 6 categorises respondents' initiatives (for example setting new goals, developing new products/services/processes/procedures) in their workplace. 
Table 5 : Prior entrepreneurial experience of respondents

\begin{tabular}{|c|c|c|c|c|c|c|c|c|c|c|c|c|c|}
\hline \multirow{4}{*}{$\begin{array}{c}\text { Type of } \\
\text { organisation }\end{array}$} & \multirow{2}{*}{$\begin{array}{l}\text { Country } \\
\text { Gender }\end{array}$} & \multicolumn{2}{|c|}{ Bulgaria } & \multicolumn{2}{|c|}{ Greece } & \multicolumn{2}{|c|}{ Iceland } & \multicolumn{2}{|c|}{ Ireland } & \multicolumn{2}{|c|}{ Portugal } & \multicolumn{2}{|c|}{ Sicily } \\
\hline & & $\mathbf{M}$ & $F$ & $\mathbf{M}$ & $\mathbf{F}$ & $\mathbf{M}$ & $\mathbf{F}$ & $\mathbf{M}$ & $\mathbf{F}$ & $\mathbf{M}$ & $\mathbf{F}$ & M & $\mathbf{F}$ \\
\hline & No & 1 & 4 & 2 & 9 & 3 & 4 & 5 & 5 & 28 & 67 & 2 & 1 \\
\hline & Total F/M & 3 & 6 & 12 & 17 & 9 & 11 & 16 & 14 & 43 & 85 & 3 & 1 \\
\hline \multirow{3}{*}{ Voluntary } & Yes & 2 & 4 & - & - & 4 & 9 & 4 & 4 & 10 & 3 & 10 & 6 \\
\hline & No & 2 & 1 & - & - & 0 & 0 & 0 & 1 & 6 & 1 & 2 & 1 \\
\hline & Total F/M & 4 & 5 & - & - & 4 & 9 & 4 & 5 & 16 & 4 & 12 & 7 \\
\hline \multirow{3}{*}{$\begin{array}{c}\text { Social } \\
\text { Enterprise }\end{array}$} & Yes & 8 & 8 & 7 & 6 & 2 & 5 & 3 & 4 & 22 & 8 & 12 & 11 \\
\hline & No & 3 & 13 & 3 & 4 & 0 & 0 & 2 & 2 & 15 & 16 & 0 & 6 \\
\hline & Total F/M & 11 & 21 & 10 & 10 & 2 & 5 & 5 & 6 & 37 & 24 & 12 & 17 \\
\hline \multicolumn{2}{|c|}{ Total no. of $M / F$ per country } & 18 & 32 & 22 & 27 & 15 & 25 & 25 & 25 & 96 & 113 & 27 & 25 \\
\hline \multicolumn{2}{|c|}{ Total no. of respondents } & \multicolumn{2}{|c|}{50} & \multicolumn{2}{|c|}{49} & \multicolumn{2}{|c|}{40} & \multicolumn{2}{|c|}{50} & \multicolumn{2}{|c|}{209} & \multicolumn{2}{|c|}{52} \\
\hline
\end{tabular}

[F-females, M-males, Yes-respondents with experience, No-respondents without experience] 
Table 6: Types of organisations started/initiated by respondents

\begin{tabular}{|c|c|c|c|c|c|c|c|c|c|c|c|c|c|}
\hline \multirow{2}{*}{ Sector } & \multirow{2}{*}{$\begin{array}{l}\text { Country } \\
\text { Types of org. }\end{array}$} & \multicolumn{2}{|c|}{ Bulgaria } & \multicolumn{2}{|c|}{ Greece } & \multicolumn{2}{|c|}{ Iceland } & \multicolumn{2}{|c|}{ Ireland } & \multicolumn{2}{|c|}{ Portugal } & \multicolumn{2}{|c|}{ Sicily } \\
\hline & & $\mathbf{M}$ & $\mathbf{F}$ & $\mathbf{M}$ & $\mathbf{F}$ & $\mathbf{M}$ & $\mathbf{F}$ & M & $\mathbf{F}$ & M & $\mathbf{F}$ & M & $\mathbf{F}$ \\
\hline \multirow{9}{*}{ Public } & O.B. & & & 8 & 4 & 4 & 6 & 4 & 1 & 15 & 12 & & \\
\hline & Club & 1 & & 2 & 1 & 4 & 2 & 5 & 5 & & 6 & 1 & \\
\hline & Society & & 1 & & & 2 & & 2 & 3 & & & & \\
\hline & Vol. Gr. & 1 & & & 2 & 2 & 1 & 5 & 3 & & & 1 & \\
\hline & Intrst. Gr. & & 1 & & 1 & 2 & & 4 & 2 & & & & \\
\hline & Lobby Gr. & & & & & 4 & 3 & 1 & & & & & \\
\hline & Other & & & 1 & 1 & 1 & 1 & 1 & 1 & & & & \\
\hline & $\begin{array}{l}\text { No. of } M / F \\
\text { with past } \\
\text { experience }\end{array}$ & 2 & 2 & 10 & 8 & 6 & 7 & 11 & 9 & 15 & 18 & 1 & 0 \\
\hline & $\begin{array}{l}\text { No. of } \\
\text { organisations }\end{array}$ & 2 & 2 & 11 & 9 & 19 & 13 & 20 & 15 & 15 & 18 & 3 & 0 \\
\hline \multirow{9}{*}{ Voluntary } & O.B. & & 2 & - & - & 1 & 3 & 3 & 4 & 4 & 1 & 1 & \\
\hline & Club & 1 & 1 & - & - & 1 & 3 & 1 & 2 & 1 & 1 & & \\
\hline & Society & & 1 & - & - & & 3 & 1 & 2 & & 1 & 2 & 2 \\
\hline & Vol. Gr. & 1 & & - & - & 1 & 2 & 2 & 2 & 3 & & 4 & 2 \\
\hline & Intrst. Gr. & & & - & - & & 1 & & & & & 1 & 1 \\
\hline & Lobby Gr. & & & - & - & 1 & 2 & & 1 & 1 & & & \\
\hline & Other & & & - & - & & 2 & & & 1 & & 2 & 1 \\
\hline & $\begin{array}{l}\text { No. of } M / F \\
\text { with past } \\
\text { experience }\end{array}$ & 2 & 4 & - & - & 4 & 9 & 4 & 4 & 10 & 3 & 10 & 6 \\
\hline & $\begin{array}{l}\text { No. of } \\
\text { organisations }\end{array}$ & 2 & 4 & - & - & 4 & 16 & 7 & 11 & 10 & 3 & 10 & 6 \\
\hline \multirow{9}{*}{$\begin{array}{l}\text { Social } \\
\text { Enterprise }\end{array}$} & $O . B$ & 5 & 8 & 3 & 3 & 1 & 5 & 2 & 4 & 12 & 4 & 4 & \\
\hline & Club & 1 & & 3 & 2 & & & 2 & 1 & & & & \\
\hline & Society & 1 & 1 & & & & & & 2 & 5 & & 2 & 1 \\
\hline & Vol. Gr. & 1 & & 1 & & & & 1 & 2 & 5 & 4 & 3 & 6 \\
\hline & Intrst. Gr. & & 1 & 2 & & 1 & & 1 & 1 & & & 1 & 3 \\
\hline & Lobby Gr. & & & & & & 1 & 1 & & & & & \\
\hline & Other & & & 1 & 3 & & 1 & 1 & & & & 2 & 1 \\
\hline & $\begin{array}{l}\text { No. of } M / F \\
\text { with past } \\
\text { experience }\end{array}$ & 8 & 8 & 7 & 6 & 2 & 5 & 3 & 4 & 22 & 8 & 12 & 11 \\
\hline & $\begin{array}{l}\text { No. of } \\
\text { organisations }\end{array}$ & 8 & 10 & 9 & 8 & 2 & 7 & 8 & 10 & 22 & 8 & 12 & 11 \\
\hline \multicolumn{2}{|c|}{ Total no. of respondents } & \multicolumn{2}{|c|}{50} & \multicolumn{2}{|c|}{56} & \multicolumn{2}{|c|}{40} & \multicolumn{2}{|c|}{50} & \multicolumn{2}{|c|}{209} & \multicolumn{2}{|c|}{52} \\
\hline
\end{tabular}

[O.B. - owner of the business; F-females, M-males; Gr. - group; Intrst.-interest group; Other- another type of organisation stated by respondents;

No. of organisations- the total number of organisations started by males/females in that sector]

Table 5 shows that most of the respondents had past entrepreneurial experience (outside of their workplace), with Iceland at $83 \%$ (33 out 40 ) Sicily at $77 \%$ (40 out of 52 ), Ireland at $74 \%$ (35 out of 50 ) with the highest number of respondents, followed by those in Greece at $63 \%$ (31 out of 50) and Portugal, at only 36\% (76 out of 209). Table 6 explores the findings as to whether respondents behave entrepreneurially in their current organisation; that is if they ever initiated or improved work goals, processes, product/services or procedures within their organisations. Overall most of the respondents across the three sectors, except some females from the public sector in Bulgaria and male respondents in Sicily, indicated that, in their view, most 
of them "contributed" in various ways in their organisations' operations, either internal ones (i.e. setting goals, revision of processes or procedures) or external improvements.

As regards respondents' type of improvements (see Table 7) in the public sector the data indicates that most of the employees have contributed in various ways to their organisations, and main areas of improvement include: "services" in Greece $(79 \%)$, "processes" in Ireland (90\%), and "goals" in both Iceland (65\%) and in Portugal (30\%). It was also interesting to see that in Portugal all respondents across all three sectors stated they took a very proactive approach to improvements at work, with each respondent claiming that he/she has contributed to at least one improvement at work.

Table 7: Improvements made by respondents in their respective organisations

\begin{tabular}{|c|c|c|c|c|c|c|c|c|c|c|c|}
\hline \multirow[b]{2}{*}{ Sector } & \multirow{2}{*}{$\begin{array}{l}\text { Country } \\
\text { Types of } \\
\text { improvement }\end{array}$} & \multicolumn{2}{|c|}{ Bulgaria } & \multicolumn{2}{|c|}{ Greece } & \multicolumn{2}{|c|}{ Iceland } & \multicolumn{2}{|c|}{ Ireland } & \multicolumn{2}{|c|}{ Portugal } \\
\hline & & $\mathbf{M}$ & $\mathbf{F}$ & M & $F$ & $\mathbf{M}$ & $\mathbf{F}$ & M & $\mathbf{F}$ & $\mathbf{M}$ & $\mathrm{F}$ \\
\hline \multirow{8}{*}{ Public } & Goals & 0 & 1 & 3 & 3 & 7 & 6 & 13 & 8 & 14 & 24 \\
\hline & Products & 1 & 0 & 2 & 2 & 3 & 3 & 6 & 4 & 8 & 9 \\
\hline & Services & 1 & 1 & 11 & 12 & 6 & 7 & 13 & 10 & 11 & 17 \\
\hline & Processes & 1 & 2 & 0 & 0 & 3 & 7 & 14 & 13 & 4 & 19 \\
\hline & Procedures & 0 & 2 & 8 & 10 & 5 & 7 & 2 & 13 & 6 & 16 \\
\hline & Other & 0 & 0 & 0 & 0 & 0 & 0 & 1 & 0 & 0 & 0 \\
\hline & Yes & 3 & 3 & 11 & 12 & 7 & 7 & 14 & 13 & 43 & 85 \\
\hline & Total No. M/F & 3 & 6 & 12 & 17 & 9 & 11 & 16 & 14 & 43 & 85 \\
\hline \multirow{8}{*}{ Voluntary } & Goals & 1 & 2 & - & - & 4 & 7 & 4 & 4 & 6 & 1 \\
\hline & Products & 0 & 1 & - & - & 3 & 6 & 2 & 3 & 4 & 1 \\
\hline & Services & 1 & 0 & - & - & 3 & 9 & 4 & 4 & 4 & 1 \\
\hline & Processes & 1 & 2 & - & - & 2 & 6 & 3 & 4 & 2 & 1 \\
\hline & Procedures & 1 & 0 & - & - & 2 & 6 & 4 & 2 & 0 & 0 \\
\hline & Other & 0 & 0 & - & - & 0 & 0 & 0 & 1 & 0 & 0 \\
\hline & Yes & 2 & 4 & - & - & 4 & 9 & 4 & 5 & 16 & 4 \\
\hline & Total No. M/F & 4 & 5 & - & - & 4 & 9 & 4 & 5 & 16 & 4 \\
\hline \multirow{8}{*}{$\begin{array}{c}\text { Social } \\
\text { Enterprise }\end{array}$} & Goals & 2 & 3 & 1 & 3 & 2 & 1 & 5 & 5 & 16 & 12 \\
\hline & Products & 1 & 2 & 0 & 1 & 1 & 4 & 3 & 2 & 5 & 8 \\
\hline & Services & 3 & 7 & 8 & 6 & 1 & 3 & 4 & 3 & 5 & 1 \\
\hline & Processes & 3 & 5 & 0 & 0 & 2 & 1 & 3 & 3 & 8 & 2 \\
\hline & Procedures & 2 & 4 & 6 & 7 & 2 & 2 & 4 & 0 & 3 & 1 \\
\hline & Other & 0 & 0 & 0 & 0 & 0 & 0 & 3 & 0 & 0 & 0 \\
\hline & Yes & 6 & 12 & 8 & 7 & 2 & 4 & 5 & 5 & 37 & 24 \\
\hline & Total No. M/F & 11 & 21 & 10 & 10 & 2 & 5 & 5 & 6 & 37 & 24 \\
\hline \multicolumn{2}{|c|}{ Total No. of respondents } & \multicolumn{2}{|c|}{50} & \multicolumn{2}{|c|}{49} & \multicolumn{2}{|c|}{40} & \multicolumn{2}{|c|}{50} & \multicolumn{2}{|c|}{209} \\
\hline
\end{tabular}

[Total No. of M/F - total number of females and males per each sector type] (Source: authors) 
On the other hand, the data indicates that respondents in the public sector, especially females in Bulgaria and males in Sicily, appear to behave less proactively or entrepreneurially in their organisations. Moreover, it is interesting to see that from the three male employees in the public sector in Sicily, with one holding a "middle management" role and the other two "senior executive" roles, none of them has ever contributed or improved any processes, services, or goals in his respective organisations.

\subsection{Entrepreneurial orientation of organisations}

The final section of the questionnaire asked respondents if their organisation requires them to be entrepreneurially oriented or not within their workplace and explored the level of encouragement, empowerment and the need for innovative/creative behaviour in their respective organisations (see Table 8).

Table 8: Encouragement, empowerment and the importance of innovative/creative behaviour in the organisation

\begin{tabular}{|c|c|c|c|c|c|c|c|c|c|c|c|c|c|c|c|c|c|c|c|c|c|c|c|c|c|}
\hline & & \multicolumn{4}{|c|}{ Bulgaria } & \multicolumn{4}{|c|}{ Greece } & \multicolumn{3}{|c|}{ Iceland } & & \multicolumn{3}{|c|}{ Ireland } & \multicolumn{5}{|c|}{ Portugal } & \multicolumn{4}{|c|}{ Sicily } \\
\hline & Sector & \multicolumn{2}{|c|}{$M$} & \multicolumn{2}{|c|}{$\mathbf{F}$} & \multicolumn{2}{|c|}{$M$} & \multicolumn{2}{|c|}{$F$} & \multicolumn{2}{|c|}{ M } & \multicolumn{2}{|l|}{$\mathbf{F}$} & \multicolumn{2}{|l|}{$M$} & \multicolumn{2}{|l|}{$F$} & \multicolumn{2}{|l|}{$M$} & \multicolumn{2}{|l|}{$F$} & \multicolumn{2}{|l|}{$M$} & \multicolumn{2}{|c|}{$F$} \\
\hline & Yes/No & $\mathbf{Y}$ & $\mathbf{N}$ & $Y$ & $\mathbf{N}$ & $\mathbf{Y}$ & $\mathbf{N}$ & $\mathbf{Y}$ & $\mathbf{N}$ & $Y$ & $\mathbf{N}$ & $\mathbf{Y}$ & $\mathbf{N}$ & $Y$ & $\mathbf{N}$ & $\mathbf{Y}$ & $\mathbf{N}$ & $\mathbf{Y}$ & $\mathbf{N}$ & $Y$ & $\mathbf{N}$ & $\mathbf{Y}$ & $\mathbf{N}$ & $\mathbf{Y}$ & $\mathbf{N}$ \\
\hline \multirow{5}{*}{ 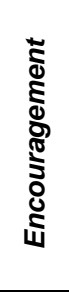 } & Public & 3 & 0 & 3 & 3 & 11 & 1 & 9 & 8 & 7 & 2 & 9 & 1 & 13 & 3 & 12 & 2 & 22 & 21 & 52 & 33 & 0 & 3 & 1 & 0 \\
\hline & Voluntary & 4 & 0 & 5 & 0 & 0 & 0 & 0 & 0 & 3 & 1 & 7 & 2 & 3 & 1 & 5 & 0 & 14 & 2 & 4 & 0 & 12 & 0 & 7 & 0 \\
\hline & Social Enterprise & 9 & 2 & 15 & 6 & 5 & 5 & 6 & 4 & 2 & 0 & 5 & 0 & 5 & 0 & 6 & 0 & 22 & 15 & 22 & 2 & 12 & 0 & 17 & 0 \\
\hline & Other & & & & & & & & & 1 & & & & & & 1 & & & & & & & & & \\
\hline & Total no. of respondents & \multicolumn{4}{|c|}{50} & \multicolumn{4}{|c|}{49} & \multicolumn{3}{|c|}{40} & \multicolumn{4}{|c|}{50} & \multicolumn{5}{|c|}{209} & \multicolumn{4}{|c|}{52} \\
\hline \multirow{5}{*}{ 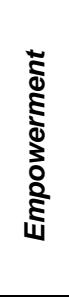 } & Public & 3 & 0 & 3 & 3 & 8 & 4 & 9 & 8 & 9 & 0 & 9 & 2 & 13 & 3 & 10 & 4 & 42 & 1 & 60 & 25 & 0 & 3 & 1 & 0 \\
\hline & Voluntary & 4 & 0 & 5 & 0 & 0 & 0 & 0 & 0 & 4 & 0 & 9 & 0 & 4 & 0 & 5 & 0 & 14 & 2 & 4 & 0 & 12 & 0 & 7 & 0 \\
\hline & Social Enterprise & 10 & 1 & 18 & 3 & 4 & 6 & 7 & 3 & 2 & 0 & 5 & 0 & 5 & 0 & 6 & 0 & 22 & 15 & 22 & 2 & 11 & 1 & 17 & 0 \\
\hline & Other & & & & & & & & & & & & & 1 & & & & & & & & & & & \\
\hline & Total no. of respondents & \multicolumn{4}{|c|}{50} & & 4 & & & & 40 & & & & 50 & & & & 209 & & & & 52 & & \\
\hline & Public & 3 & 0 & 6 & 0 & 12 & 0 & 15 & 2 & 7 & 2 & 9 & 1 & 15 & 1 & 11 & 3 & 41 & 2 & 80 & 5 & 1 & 2 & 1 & 0 \\
\hline & Voluntary & 4 & 0 & 5 & 0 & 0 & 0 & 0 & 0 & 2 & 1 & 4 & 5 & 4 & 0 & 5 & 0 & 16 & 0 & 4 & 0 & 12 & 0 & 7 & 0 \\
\hline 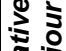 & Social Enterprise & 11 & 0 & 21 & 0 & 10 & 0 & 10 & 0 & 2 & 0 & 4 & 1 & 5 & 0 & 6 & 0 & 27 & 10 & 22 & 2 & 12 & 0 & 17 & 0 \\
\hline $\overrightarrow{0}$ & Other & & & & & & & & & 2 & & & & & & & & & & & & & & & \\
\hline & Total no. of respondents & & & & & & 4 & & & & 40 & & & & 50 & & & & 209 & & & & 52 & & \\
\hline
\end{tabular}

['Other'- additional comments made by respondents to the survey questions; Y-yes, N-no, F- females, M-males]

Employees in the public sector organisations do not appear to enjoy the same levels of decision-making empowerment and encouragement as those respondents in the voluntary sector organisations. For instance, while nearly all respondents in the voluntary sector indicated they feel empowered in decision-making processes and/or encouraged to seek new opportunities (except a small number of males in the voluntary sector in Portugal), there is a tendency that female employees in the public 
sector (for example in Bulgaria 50\%, Greece 52\% and Portugal 61\%) are not encouraged nor empowered as much as their male counterparts in their organisations. However, this may be linked to the nature of work they perform, as most of these females hold operative roles in their organisations.

As regards to the innovative/creative behaviour, Table 8 illustrates that the majority of respondents concur that it is important for employees to be creative and innovative within their work environments, with Bulgaria (50), and Ireland (47) registering the highest, followed by Sicily (except males in the public sector) and Iceland (28) with the lowest rate of consensus to this question. Overall, (5 out of 9) female respondents in the voluntary sector in Iceland and all males in the public sector in Sicily (3) indicated that they are not required to be innovative and creative in their work. This is an interesting finding considering that all males in the public sector in Sicily are in higher-management positions in their organisations, similar to those in the voluntary sector in Iceland where 6 out of 9 females hold senior executive positions.

\subsection{Discussion}

A key focus of this paper was to explore volunteers'/employees' EO in public and third sector organisations in order to identify entrepreneurial potential by determining past experience and the extent to which they behave proactively in their current job role. Another important objective was to ascertain organisations' EO and hence the level of organisational support for employees'/volunteers' entrepreneurial and innovative behaviour. For this purpose, this study adopted an EO framework which facilitated a reconciling of both perspectives of EO - the individual and the organisational which enriches the knowledge and facilities further research avenues regarding EO at the individual level. The discussion section is divided into the following three subsections.

\subsection{Past entrepreneurial experience}

The results illustrate that entrepreneurial experience was present across all sectors and countries surveyed showing strong levels in Iceland (83\%), Sicily (77\%), Ireland (74\%), Greece (63\%), and showing lower levels in Portugal (36\%). Overall, respondents in Iceland and Ireland, across all three sectors, display a high level of past entrepreneurial experience, with a relatively high number of respondents in the public sector who declared such experience (see Table 5).

Prior entrepreneurial experience incorporates a range of skills and experiences such as business planning, development and project management, but also experience and knowledge in risk-taking, teamwork, leadership and reasonability and a confidence in one's own ability (Gibb and Hannon, 2006). It is probable that prior entrepreneurial experience assists public and third sector employees in their day-today job role and how they deliver services to their customers (Cooney, 2012). Individuals with creative (and/or entrepreneurial) tendencies will, most likely, perform that way in other areas of their life; for example in their workplace. Moreover, the employees/volunteers who display high levels of past entrepreneurial experience are more alert in opportunity-seeking (Kirzner, 1979) and may be more receptive to innovation (Drucker, 1985). They may also be more capable of leveraging necessary knowledge and skills that may lead to a high number and variety of improvements, 
as appears to be in the case of respondents in Iceland, Ireland and Greece (see Table 7).

A noteworthy finding for Iceland is that the corresponding number of female respondents who registered with prior entrepreneurial experience across all three sectors is slightly higher (21 out of 25 ) than males (12 out of 15) (see Table 5); especially in the public sector where more than half of public sector females in Iceland (6 out of 11), declared they had initiated their own business. This is contrary to findings in the other countries surveyed where more males in comparison to females reported business-related past entrepreneurial experience (see Table 5). This also appears to be contrary to findings by Grilo and Thurik (2008) who suggested that females typically display lower levels of entrepreneurial engagement and enterprising behaviour than males. ${ }^{4}$

Overall, the data informs that respondents in the public and social enterprise sectors do not appear to display the same level of past entrepreneurial experience as those employees/volunteers in voluntary sector organisations, especially respondents in the social enterprise sector in Bulgaria, Greece and Portugal, where less than a half of females registered past entrepreneurial experience (see Table 5). This may suggest a reason as to why they display a lower level of entrepreneurial behaviour in their work environment (see Table 7). Furthermore, the data also indicates that, for the voluntary sector organisations across all countries (except Iceland), there are more females who indicated they had past entrepreneurial experience, in comparison to male employees. In a similar vein, in the voluntary sector organisations, it appears that more female employees take a proactive approach in improving "things" at work, in comparison to male employees; and especially female employees in Sicily, where nearly all females (6 out of 7 ) stated they have contributed, mostly, to "services" aspect in their organisations (see Table 7). This finding appears to be consistent with a study by Hopkins (2010) who reported that usually females appear to be the ones employed in the higher positions in voluntary sector organisations, hence having more freedom to nurture new opportunities at work.

Overall there was a high level of educational attainment among respondents in Greece, Ireland and Iceland (at $61 \%, 64 \%$ and $45 \%$, respectively) who attained at least a post graduate educational qualification. These respondents also displayed a relatively high level of proactive behaviour at work (at $79 \%, 90 \%$ and $70 \%$, respectively) by contributing in various ways to their organisations' "goals, processes, procedures, services and products" (see Table 7). This finding appears to coincide with a study by Jelenc, Pisapia and Ivanušić (2015), who confirmed that achievement of a high educational degree, combined with past entrepreneurial experience, creates entrepreneurs with higher levels of pro-activeness at work.

Entrepreneurial experience can come in many forms and in many cases is driven by a level of optimism (Ucbasaran et al., 2009) and therefore as a behaviour, outlook or ability, it is not solely limited to just the creation of an economic entity (Chell, 2007; Gibb, 2002). The creation of clubs, societies, voluntary or interest groups are examples of a level of individual entrepreneurial orientation and entrepreneurial

\footnotetext{
${ }^{4}$ Grilo and Thurik (2008) used data from two surveys (2002 and 2003) containing over 20,000 observations of the 15 old EU member states, Norway, Iceland, Liechtenstein and the US.
} 
spirit. Overall, what emerged from the primary findings is that organisations in which respondents indicated high levels of prior entrepreneurial experience and higher educational qualifications appear to have employees who are more proactive in improving many different aspects within their work environments. However, this is contrary to what was experienced in Portugal, where $65 \%$ of all respondents did not engage in prior entrepreneurial activity, yet all of them stated they were proactive in improving different aspects of their work, especially those employees in the public sector.

\subsection{Organisations' EO empowerment and encouragement}

The extent to which an organisation can be identified as entrepreneurial depends on the organisation's ability to empower employees/volunteers to be more creative and proactive at work (Kuratko, Hornsby and Covin, 2014; Mulgan and Albury, 2003). This view was supported by Fernandez and Pitts (2011) who suggested that empowerment and employees' involvement in decision-making processes is one of the pivotal factors that may spur bottom-up innovation in public sector organisations. However, in this study the survey data reports that many public sector respondents (75\% in Sicily, $42 \%$ in Portugal, 33\% in Bulgaria) are not encouraged to look for new opportunities, nor are they empowered in the decision- making process within their organisations (75\% in Sicily, $47 \%$ in Greece, 33\% in Bulgaria).

For instance, while nearly all respondents in the voluntary sector indicate they feel empowered in decision-making processes and/or encouraged to seek new opportunities (except a small number of males in the voluntary sector in Portugal), there is a tendency that female employees in the public sector (for example in Bulgaria 50\%, Greece 52\% and Portugal 61\%) are not encouraged nor empowered as much as their male counterparts in their organisations. However, this may be linked to the nature of work they perform, as most female respondents hold "operative" roles (see Table 3) in their organisations, hence the remit of their job description may limit their decision-making latitude, as anticipated by Wakkee, Elfring and Monaghan (2010).

According to Kuratko, Hornsby and Covin (2014) and Fernandez and Pitts (2011), one of the important drivers of employees' innovative behaviour is empowerment and perceived job autonomy that not only creates feelings of safety but also spurs the motivational state needed for generating creative solutions (and therefore improvements) at work. However, this study indicates that empowerment at lower grades (roles) may not necessarily impede one's ability to instigate different improvements at work. This was illustrated in regard to females in the public sector in Greece and Portugal, who, despite their low empowerment in their organisations, claimed they were proactive in improving many different aspects of work. Overall, it appears that respondents from voluntary sector organisations feel the most encouraged to seek new opportunities and also feel empowered in decision-making processes in their organisations, especially among female employees across all the six countries. 


\subsection{Proactive and innovative behaviour in the workplace}

With respect to innovative behaviour at work most respondents concur that it is important to behave innovatively and creatively at work with an overall high consensus among respondents in Bulgaria (100\%), Portugal (91\%), Sicily (96\%), Ireland (92\%), Greece (96\%), and Iceland (73\%). However, an unexpected finding was that the highest number of respondents who did not support this view was from Iceland $(27 \%)$. This may support the contention made by Sandberg, Humerinta and Zetting (2013) that, being entrepreneurial does not necessarily mean being innovative and some organisations (also individuals) that may be entrepreneurially orientated may not necessarily be (or wish to be) innovative (Drucker,1985).

Overall, (5 out of 9 ) female respondents in the voluntary sector in Iceland and all males in the public sector in Sicily, indicated that they are not required to be innovative and creative in their work (see Table 8). This is an interesting finding considering that all males in the public sector in Sicily are in higher-management positions in their organisations, similar to those in the voluntary sector in Iceland where 6 out of 9 females hold senior executives positions (see Table 3 ).

This paper concurs with Mair's (2005) conceptualisation of "day-to-day" entrepreneurship, where individual entrepreneurial behaviour includes a spectrum of activities, ranging from autonomous to integrative/cooperative behaviour, to find entrepreneurial ways of getting things done (i.e. at work). This research also concurs with the view of Bolton and Lane (2012) who emphasised that an understanding of an individual's EO can firstly lead to more cohesive and successful project teams and also can be valuable to future business owners, managers, educators and organisational leaders. However, in order for employees of public and third sector organisations to be able to act on their creative/entrepreneurial abilities, they need to be empowered and encouraged to do so from within their own organisations.

\subsection{Conclusions}

It is important to fully understand the entrepreneurial potential of any workforce as all individuals have the potential to think and behave entrepreneurially. The aim of this study was to identify entrepreneurial potential of employees within pubic and third sector organisations by exploring the EO of individual employees and the extent to which they can be entrepreneurial within their respective organisations. It is evident from the findings that public and third sector organisations should consider the entrepreneurial potential of their employees, taking into consideration their employees' past entrepreneurial experience. This knowledge can be used to enhance the efficiency, affectivity and service delivery of public and third sector organisations. A major contribution of this research is that it adds a new dimension to existing research on EO, especially the approach of exploring EO at employee/volunteer level in public and third sector organisations. 


\section{References}

Altinay, L. and Wang, C. L. (2011) 'The influence of an entrepreneur's socio-cultural characteristics on the entrepreneurial orientation of small firms', Journal of Small Business and Enterprise Development, 18(4), pp .673-694.

Bolton D.L. and Lane, M.D. (2012) 'Individual entrepreneurial orientation: development of a measurement instrument', Education+Training, 54(2/3), pp. 219-233.Borins, S. (2002) 'Leadership and innovation in the public sector', Leadership \& Organization Development Journal, 23(8), pp. 467-476.

Bysted, R. and Hansen, J. (2015) 'Comparing public and private sector employees' innovative behaviour: understanding the role of job and organizational characteristics, job types, and subsectors', Public Management Review, 17(5), pp. 698-717.

Chell, E. (2007) 'Social enterprise and entrepreneurship towards a convergent theory of the entrepreneurial process', International Small Business Journal, 25(1), pp. 5-26.

Cooney, T. M. (2012) 'Why Ireland needs an entrepreneurship educational policy?', Thomas M. Cooney Blog, 17 April. Available at:

http://thomascooney.ie/why-ireland-needs-an-entrepreneurship-education-policy/

(Accessed: 12 May 2015).

Cooney, T. and Murray, T. (2008) Entrepreneurship education in the third-level sector in Ireland. Institute of Minority Entrepreneurship, Dublin Institute of Technology [Online]. Available at:

http://arrow.dit.ie/cgi/viewcontent.cgi?article=1001\&context=imerep (Accessed: 17 October 2015).

Covin, J.G. and Lumpkin, G.T. (2011) 'Entrepreneurial orientation theory and research: reflections on a needed construct', Entrepreneurship Theory and Practice, 35(5), pp. 855872.

Covin, J.G. and Slevin, D.P. (1991) 'A conceptual model of entrepreneurship as firm behaviour', Entrepreneurship Theory and Practice, 16(1), pp. 7-25.

Currie, G., Humphreys, M., Ucbasaran, D. and McManus, S. (2008) 'Entrepreneurial leadership in the English public sector: paradox or possibility?', Public Administration, 86(4), pp. 987-1008.

Defourny, J. and Nyssens, M. (2010) 'Social enterprise in Europe: at the crossroads of market, public policies and third sector', Policy and Society, 29(3), pp. 231-242.

Diefenbach, F.E. (2011) Entrepreneurship in the public sector: when middle managers create public value. Wiesbaden: Gabler Verlag,

Drucker, P.F. (1985) Innovation and entrepreneurship: practice and principles. New York: Harper \& Row.

Feldman, M.P. and Francis, J.L. (2004) 'Homegrown solutions: fostering cluster formation’, Economic Development Quarterly, 18(2), pp. 127-137. 
Fernandez, S. and Pitts, D. (2011) 'Understanding employee motivation to innovate: evidence from front line employees in United States federal agencies', Australian Journal of Public Administration, 70(2). pp. 202-222.

Gibb, A.A. (2002) 'In pursuit of a new 'enterprise' and 'entrepreneurship' paradigm for learning: creative destruction, new values, new ways of doing things and new combinations of knowledge', International Journal of Management Review, 4(3), pp. 233-69.

Gibb, A.A. and Hannon, P. (2006) 'Towards the entrepreneurial university', International Journal of Entrepreneurship Education, 4(1), pp. 73-110.

Grilo, I. and Thurik, R. (2008) 'Determinants of entrepreneurial engagement levels in Europe and the US', Industrial and Corporate Change, 17(6), pp. 1113-1145.

Grover, C. and Piggott, L. (2012) 'Economic crisis, need \& voluntary organisations in the Lancaster district: a report for Lancaster District Community Voluntary Solutions'. Available at:

lancastercvs.org.uk/wp-content/uploads/2014/06/economic-crisis-and-need.pdf (Accessed: 10 May, 2017).

Hopkins, L. (2010) Mapping the third sector: a context for social leadership. A report prepared for Clore Social Leadership Programme. London: The Work Foundation.

Jelenc, L., Pisapia, J. and Ivanušić, N. (2015) 'Demographic variables influencing individual entrepreneurial orientation and strategic thinking capability', Proceedings of 10th International Scientific Conference on Economic and Social Development, 2015. Available at:

https://ssrn.com/abstract=2715121 (Accessed: 10 May 2017).

Kearney, C., Hisrich, R. and Roche, F. (2008) 'A conceptual model of public sector corporate entrepreneurship', International Entrepreneurship and Management Journal, 4(3), pp. 295313.

Kim, Y. (2010) 'Stimulating entrepreneurial practices in the public sector: the roles of organizational characteristics', Administration and Society, 42(7), pp. 780-814.

Kirzner, I.M. (1979) Perception, opportunity, and profit. Chicago: University of Chicago.

Kraus, S. (2013) 'The role of entrepreneurial orientation in service firms: empirical evidence from Austria', The Service Industries Journal, 33(5), pp. 427-444.

Kuratko, D.F., Hornsby, J.S. and Covin, J.G. (2014) 'Diagnosing a firm's internal environment for corporate entrepreneurship', Business Horizons, 57(1), pp. 37-47.

Lee, S.M. and Peterson, S.J. (2000) 'Culture, entrepreneurial orientation, and global competitiveness', Journal of World Business, 35(4), pp. 401-416.

Lumpkin, G.T. and Dess, G.G. (2001) 'Linking two dimensions of entrepreneurial orientation to firm performance: the moderating role of environment and industry life cycle', Journal of Business Venturing, 16(5), pp. 429-451.

Lumpkin, G.T. and Dess, G.G. (1996) 'Clarifying the entrepreneurial orientation construct and linking it to performance', The Academy of Management Review, 21(1), pp. 135-172.

Mair, J. (2005) 'Entrepreneurial behaviour in a large traditional firm: exploring key drivers', in Elfring, T. (ed.) Corporate Entrepreneurship and Venturing. New York: Springer, pp. 49-72.

Miller, D. (1983) 'The correlates of entrepreneurship in three types of firms', Management Science, 29(7), pp. 770-791. 
Miller, D. (2011) 'Miller (1983) revisited: a reflection on EO research and some suggestions for the future', Entrepreneurship Theory and Practice, pp.873-894.

Moore, M. (1995) Creating public value: strategic management in government. Cambridge, MA: Harvard University Press.

Morris, M.H. and Kuratko, D.F. (2002) Corporate Entrepreneurship. Manson, OH: SouthWestern College Publishers.

Morris, M.H., Webb, J.W. and Franklin, R.J. (2011) 'Understanding the manifestation of entrepreneurial orientation in the nonprofit context', Entrepreneurship Theory and Practice, 35(5), pp. 947-971.

Mulgan, G. and Albury, D. (2003) Innovation in the public sector. London: Prime Minister's Strategy Unit/Cabinet Office.

Okhomina, D. (2010) 'Entrepreneurial orientation and psychological traits: the moderating influence of supportive environment', Journal of Behavioral Studies in Business, 2, pp. 1-16.

Rauch, A., Wiklund, J., Lumpkin, G.T. and Frese, M. (2009) 'Entrepreneurial orientation and business performance: an assessment of past research and suggestions for the future', Entrepreneurship Theory and Practice, 33(3), pp. 761-787.

Sandberg, B., Humerinta, L. and Zetting, P. (2013) 'Highly innovative and extremely entrepreneurial individuals: what are these rare birds made of?', European Journal of Innovation Management, 16(2), pp. 227-242.

Stewart, J. (2014) 'Implementing an innovative public sector program: the balance between flexibility and control', International Journal of Public Sector Management, 27(3), pp. 241250.

Steyaert, C. and Katz, J. (2004) 'Reclaiming the space of entrepreneurship in society: geographical, discursive and social dimensions', Entrepreneurship and Regional Development, 16(3), pp. 179-196.

Ucbasaran, D., Westhead, P., Wright, M. and Flores, M. (2010) 'The nature of entrepreneurial experience, business failure and comparative optimism', Journal of Business Venturing, 25(6), pp. 541-555.

Venables, T. (2015) Rough Guide to the Impact of the Crisis on the Third Sector in Europe. CIRIEC Working Papers 1507, CIRIEC - Université de Liège. Available at: https://ideas.repec.org/p/crc/wpaper/1507.html (Accessed: 17 October 2015).

Wakkee, I., Elfring, T. and Monaghan, S. (2010) 'Creating entrepreneurial employees in traditional service sectors', International Entrepreneurship and Management Journal, 6(1), pp. 1-21.

Westrup, U. (2013) 'Internal entrepreneurship in the public sector: the challenges of integrating innovative project into the regular organization', Scandinavian Journal of Public Administration, 16(4), pp. 97-112.

Wiklund, J. and Shepherd, D. (2005) 'Entrepreneurial orientation and small business performance: a configurational approach', Journal of Business Venturing, 20(1), pp. 71-91.

Zampetakis, L.A. and Moustakis, V.S. (2010) 'An exploratory research on the factors stimulating corporate entrepreneurship in the Greek public sector', International Journal of Manpower, 31(8), pp. 871-88. 
Anna Rogowska et al.

Zerbinati, S. and Souitaris, V. (2005) 'Entrepreneurship in the public sector: a framework of analysis in European local governments', Entrepreneurship and Regional

Development, 17(1), pp. 43-64. 